\title{
Growth of Home Shopping Websites and Consumers ${ }^{e e}$ Preferences: With Special Reference to Kokrajhar District
}

\author{
Dhruba Jyoti Nath \\ Assistant Professor, Kokrajhar Govt. College Kokrajhar, Assam
}

\begin{abstract}
Home shopping allows consumers to shop for goods from the privacy of their own home, as opposed to traditional shopping, which requires one to visit shopping malls. In-home shopping has grown significantly since the advent of direct-response television, interactive television, infomercials, and cable network shopping channels. Product information is delivered to consumers at home via direct-mail promotions, catalogs, print advertisements, broadcast media, and outbound telephone. Recently, the term "online shopping" which is also a part of home shopping gains wide popularity. It is the act of purchasing products or services over the Internet. Online shopping has grown in popularity over the years, mainly because people find it convenient and easy to bargain shop from the comfort of their home or office. This paper tries to highlight the importance of home shopping websites in the current scenario with special reference to Kokrajhar District of Assam to compare various home shopping websites and services offered by them to the users. An attempt is being made to know the effect of home shopping websites on different age groups, to know the reasons for using this websites and the benefits they are deriving from this. This paper deals with the relevance and usefulness of home shopping websites to the society.
\end{abstract}

Keywords: Home Shopping, online shopping, e-commerce, consumers"e preferences, websites

\section{Introduction}

The number of Internet users around the world has been steadily growing and this growth has provided the impetus and the opportunities for global and regional e-commerce. However with Internet, different characteristics of the local environment, both infrastructural and socioeconomic, have created a significant level of variation in the acceptance and growth of e-commerce in different regions of the world. Among the different and extensive use of internet, home shopping is one of the widely increasing part of the same. Home shopping, also known as and a part of e-commerce, commonly refers to the electronic retailing channels industry, which includes such billion dollar television-based and e-commerce companies as Liquidation channel, HSN, QVC, Jewelry Television, Patagroup.com, eBay, Shop NBC, Bay.com, and Amazon as well as traditional mail order and Brick and Mortar retailers as Hammacher Schlemmer and Sears, Roebuck and Co. It should be mentioned here that there is a little difference between home shopping and e-commerce. Electronic commerce, commonly known as e-commerce is a type of industry where buying or selling of product and services is conducted over electronic system such as the internet and other computer network while online shopping is a act of purchasing product of services over the internet. On the other hand, home shopping is a broader sense of purchasing product or services not only through internet but with different alternative media like internet, TV, Radio, print media etc. also.

There are three main types of home shopping: mail or telephone ordering from catalogs; telephone ordering in response to advertisements in print and electronic media (such as periodicals, TV and radio); and online shopping.

The home shopping is an electronic retailing industry, was created in 1977, when small market talk radio show host Bob Circosta, America's first ever TV home shopping host was asked to sell avocado-green-colored can openers live on the air by station owner Bud Paxson. Paxson then realized the vast sales potential of home-based commerce, and founded with Roy Speer the world's first shopping channel on cable television in 1982, later launching nationwide with the Home Shopping Network (rebranded as HSN) in 1985.

In 1994, a computer scientist Jeff Bezos created Amazon.com as an online book store. In addition to books, Amazon eventually added video games, computer software, electronics, apparel, and more to its sales repertoire. The company now generates approximately eight-and-a-half billion dollars annually.

Home shopping through online gives many advantages like easy searching, comparing values and prices and it involves sometime free shipping also. Contrary, the disadvantages includes like waiting long periods of time to receive the product, lack of physical verifications of the product before one can buy it. Another factor to remember about return policy. One will have to pay the charge for shipping it back, repackaging, and stocking in most cases, unless it's a manufacturing problem. People worry about fraud or theft with credit cards purchases and uncomfortable privacy policy of the companies.

\section{Objectives}

- To know consumer preference of home shopping websites.

- To compare of different home shopping websites and their services offered.

- To study the reasons for using home shopping sites by consumers.

- To know the effect of various home shopping websites on different age groups.

\section{Volume 4 Issue 12, December 2015}




\section{International Journal of Science and Research (IJSR) \\ ISSN (Online): 2319-7064}

Index Copernicus Value (2013): 6.14 | Impact Factor (2014): 5.611

- To study whether home shopping websites are really useful to for effective shopping or not.

\section{Scope of the Study}

The study is confined to "A survey on consumer preference on different home shopping websites in present scenario" in Kokrajhar. To conduct the study, questionnaire has been selected and administered to various consumers randomly situated at different areas within district. The sample size of the study is 150 .

\section{Need for the Study}

The need of the study is to know the consumer preference on home shopping websites, to know the reasons and effects of various home shopping websites on different age groups and its uses. The need is to know whether home shopping websites are really useful to for effective shopping or not.

\section{Research Methodology}

The study and findings are based on the data collected from two important resources. They are:

- Primary data collected with the help of questionnaires.

- Secondary data collected from internet, magazines, newspapers and internet.

\section{Sample Size}

The sample size for the study is 150 . Sample constitutes people of different age groups, students, employed and unemployed male and female of the district.

\section{Area of the Study}

Today as the online shopping grows in popularity more people are turning to online shopping for all their needs. Clothes, shoes, products, even groceries can now are purchased via the internet. A lot of pros have come from this; no waiting in lines or in traffic, one can shop from the convenience of his home, easier to do comparison shopping, discounts and you can shop at any time without restrictions. This revolution influenced worldwide and touches even smaller towns like Kokrajhar also.

It came into existence as a sub-division in 1957 and was eventually notified as a district in 1983 with its head quarter at Kokrajhar by dividing Goalpara district. It is the Head Quarter of the district as well as Bodoland Territorial Council. The district is bounded by the Chirang district, Dhubri district and the foothills of Bhutan and a part of West Bengal. Its total geographical area is 3169.22 sq. Kms.

Kokrajhar district lies roughly within $89^{\circ} 46^{\text {ee }}$ East to $90^{\circ} 38^{\text {ee }}$ East and $26^{\circ} 19^{\mathrm{ee}}$ North to $26^{\circ} 54^{\mathrm{ee}}$ North Latitude. Population of this district is $8,86,999$ as per 2011 census with female population $4,34,038$. The literacy rate is $66.63 \%$ with male $73.44 \%$ female $59.54 \%$. The sex ratio in Kokrajhar is 958 female against 1000 male. Further, it is found from the census that it is 961 female in rural and 931 female against 1000 male in urban areas of the district. The population density is 280 per square KM. The rural urban population composition of the district is $8,32,201(93.81 \%)$ in the rural and $54,941(6.19 \%)$ in the urban areas as against $85.9 \%$ in rural and $14.10 \%$ in urban in the state of Assam.

\section{History of Home Shopping In India}

There is no literature on home shopping found in India. From the primary sources it is found that in some early eighties, a very limited Ayurvedic medicines were shopped. Home shopping on that time was created through advertisement on Newspapers and some magazines and its delivery system was through India post only. During that time, number of fraud cases were reported. In latter times, there is an increase in the home shopping of books and magazines. Among them, some competitive examinations related magazines are noteworthy. From 1991 onwards with the effect of globalization in India, growth of home shopping starts. Some of the important shopping sites marketed in India are mentioned below:

\subsection{Shoppers Stop(1991)}

Shoppers Stop is an Indian department store chain promoted by the K Raheja Corp Group (Chandru L Raheja Group), started in the year 1991 with its first store in Andheri, Mumbai Shoppers Stop Ltd has been awarded "the Hall of Fame" and won "the Emerging Market Retailer of the Year Award", by World Retail Congress at Barcelona, on April 10, 2008. Shoppers Stop is listed on the BSE. In 2013, Shoppers Stop has 61 stores in India. The URL of the company is http://www.shoppersstop.com/

\subsection{Indiatimes Shopping (2000)}

Indiatimes Shopping is the ecommerce division of the The Times of India Group, India's largest media conglomerate. It is one of the pioneers in electronic commerce in India and services its customers through various channels including online and selling over phone. It also provides platform services for brands to go online and sell their products in partnership through White-label. Some of the major categories sold through Indiatimes Shopping include men \& women footwear, apparel \& accessories, lifestyle, home décor, mobile phones, consumer electronics, health \& personal beauty products, books, jewellery, baby products and flowers \& gifts. Indiatimes Shopping currently operates through a hybrid model which is a mix of warehousing and marketplace.

\subsection{Seventymm(2005)}

Seventymm Services Pvt. Ltd. is an Indian online shopping company. The company originally started as an online DVD rental. Later it expanded into selling. As on Feb 2012, it shutdown its DVD rental business and solely does the online shopping business. Krishna Durvasula, founder of Seventymm.com.The URL of the company is http://www.Seventymm.com/

\section{Volume 4 Issue 12, December 2015}




\section{International Journal of Science and Research (IJSR)}

ISSN (Online): 2319-7064

Index Copernicus Value (2013): 6.14 | Impact Factor (2014): 5.611

\section{4 eBay India (2005)}

Ebay was founded as AuctionWeb in San Jose, California, on September 5, 1995 by French-bornIranianAmerican computer programmer Pierre Omidyar and soon became a notable multi-billion dollar business with operations localized in over thirty countries. The company manages http://www.eBay.com as centre of their online spread.

Ebay is the world's most popular marketplace which only acts as a mediator to connect consumers and merchants/retailers. Ebay also offers its great service in India as "Ebay India" in the year 2005. Ebay India has far more product listing than any other online seller in India, almost everything can be found on their website from Antiques to Latest gadgets. The company manages http://www.ebay.in for the operations in India.

\subsection{Pay Mate (2006)}

PayMate is a mobile commerce company that has built the largest mobile payments network in India based in Mumbai. Pay Mate enables people to transact and make payments from anywhere with their mobile phone. PayMate allows the transactions like buying flight, train and movie tickets, online and retail shopping, purchasing life insurance, and everyday transactions like shopping or dining out. Founded in May 2006 by Ajay Adiseshann, the PayMate service works on all phone operators in India. In 2008, PayMate expanded to Sri Lanka by partnering with the Bank of Ceylon. The URL of the company is www.paymate.com/

\subsection{Flipkart (2007)}

Flipkart is the most popular shopping site in India, they sell more than one lakh products daily and hence the biggest online seller in India. Flipkart was founded in 2007 by Sachin Bansal and Binny Bansal, both alumni of the Indian Institute of Technology (IIT), Delhi. They worked for Amazon.com before quitting and founding their own company. Initially they used word of mouth marketing to popularize their company. The company manages http://www.flipkart.com for its operations.

Today, as per Alexa traffic rankings, Flipkart is among the top 15 Indian Web sites and has been credited with being India's largest online seller \& bookseller.

\subsection{Myntra (2007)}

Myntra is ranked amongst the top online fashion retailers, It was founded by Mukesh Bansal, Ashutosh Lawania, and Vineet Saxena, a group of IIT/IIM graduates in 2007 and today it has its headquarter in Bangalore. Myntra was originally started as an online destination for personalized products, but later it has been expanded into a broader lifestyle and fashion retailing. Today, Myntra is very large online lifestyle retailer with over 500 nationally and internationally known brands under its banner. For its operation, the company maintains its web site http://www.myntra.com.

\subsection{Tradus (2007)}

Tradus is not just a participant in the race of online retailing, Tradus.com is an Indian venture of a European auction company, according to them they provide goods at wholesale prices on branded products, which really seems to be cheaper than any other e-store pricing. Its site address is http://www.tradus.com.

\subsection{Infibeam (2007)}

Infibeam.com is an e-commerce website with headquarter situated in Ahmedabad, India. It is basically an online retailer for books, electronics, and automobiles but also serve in many other categories. It was founded in 2007, the company has offices in Delhi, Mumbai and Bangalore, and has a total of 600+ employees. Site address is http://www.infibeam.com.

\subsection{Inkfruit (2007)}

Inkfruit is an online shopping store, not available now for submitting designs where t-shirt designs are submitted and voted for by a community. It was launched in December 2007 (then called Gnome) by Fingerprints Fashion Inc., based in Mumbai, India. An undergraduate of IIT Bombay and graduated from IIM Lucknow known as Kashyap Dalal, is the CEO of Inkfruit. The URL of the company is http://www.inkfruit.com/.

In February 2013, Inkfruit with Zovi (another online retailer of garments of India) done a tie-up Both these companies merge to keep-up with increasing competition with others online stores.

\subsection{HomeShop18 India (2008)}

HomeShop 18 was conceptualized in 2006 and grew to be a fully fledged $24 \times 7$ shopping channel in 2008 by Sundeep Malhotra. The web business www.homeshop18.com was launched in 2011. Within 2 years of launch, today the website is amongst India s top 5 online shopping brands. In 2013, HomeShop18 forayed into M Commerce with a unique model called Scan N Shop, Indiaes first virtual shopping wall at Delhi Airport. Today his vision and leadership has helped HomeShop18 to become a leading virtual retail brand in India that operates across TV, Web and Mobile platforms.

\subsection{Naaptol (2008)}

Naaptol registered as Naaptol Online Shopping Pvt Ltd, headquartered in Mumbai, Maharashtra and Kathmandu, Bagmati, Nepal is an e-commerce portal based in India and Nepal. Founded in 2008 by Manu Agarwal, Naaptol started its operation as product research and price comparison engine. Later in 2009 it was expended as an online market place and started offering products to purchase online in categories like mobiles, tablets, cameras, home appliances and a variety of other products.

In 2010, Naaptol started investing in print media and increased its print media market share by $0.3 \%$ with top 3 position for two consecutive years. Naaptol has raised 


\section{International Journal of Science and Research (IJSR) \\ ISSN (Online): 2319-7064 \\ Index Copernicus Value (2013): 6.14 | Impact Factor (2014): 5.611}

funding from New Enterprise Associates (NEA), Canaan Partners and Silicon Valley Bank during its journey since 2008 and launched a site Naaptol Club and forayed into television. Naaptol.com was also conferred with "New Brand Award" in 2011 by Star News.

\subsection{Yebhi (2009)}

Yebhi.com is an Indian Online shopping E-commerce portal for Home, Lifestyle \& Fashion e-retailer, launched in the year 2009 by Man Mahan Agrawal, Nitin Agarwal, Rajul Jain and Danish Ahmed. It powered the sale of multi brand Footwear online. Enormous success in the footwear category inspired us to expand into other categories like Apparels, Accessories, Bags, Jewellery and Mobiles.

\subsection{Snap Deal (2010)}

Snapdeal.com was founded by Kunal Bahl, a Wharton graduate and Rohit Bansal, an alumnus of IIT Delhi in February 2010, as a daily deal platform, but later they expanded their services into product retailing across various categories. Snapdeal claims to have a subscriber base of around 18 million which regularly receive deals and has their services in across 50 cities in India.

\subsection{ShopClues (2011)}

ShopClues.com is the India's 2nd largest managed marketplace for connecting buyers and sellers together, Founded in July 2011 in Silicon Valley. They provide great service with their effective Return Policy and Buyer protection policies. Site Address/URL http://www.shopclues.com/

\subsection{Jabong (2012)}

Jabong is the fast grown online shopping site, launched in 2012 and became the most popular shopping portal specially targeting fashion products. It was co-founded by Lakshmi Potluri, Arun Chandra Mohan, Praveen Sinha, Manu Jain and Mukul Bafana. This e-store at present carries over 700 brands and over 50,000 products. http://www.Jabong.com offers same-day delivery in Delhi/NCR, and within 48 hours in other cities.

\subsection{Pepperfryv(2012)}

Pepperfry. com is a furniture and home online marketplace headquartered in Mumbai. A managed marketplace, Pepperfry is known for its differentiated product range across categories like Furniture, Home Décor, Furnishings, Lamps \& Lighting, Kitchen \& Dining, Appliances, Appliances, Bath, Housekeeping and Pet Supplies.

\subsection{Junglee (2012)}

Although this is coming on that 10th position on this list I have a lot more expectations than any other marketplace above, because it is an Indian venture of the world se s biggest and most popular e-Commerce website Amazon.com.
Junglee was launched in Feb 2012 and at the time of launch, Junglee.com had more than 11 million in-stock offers from $400+$ online sellers and 2000 brands connected to them already. Site Address/URL - http://www.junglee.com/

\section{Data Analysis and Techniques}

The tools and techniques used for data analysis are tables, and percentage methods. On the basis of information generated from the data analysis, conclusions have been drawn and suitable suggestions are made.

Table1: Showing Age Group of the Respondents

\begin{tabular}{|c|c|c|}
\hline Age group & No. of respondents & $\%$ \\
\hline Below 15 & 0 & 0 \\
\hline $16-25$ & 47 & 31.3 \\
\hline $26-45$ & 67 & 44.7 \\
\hline Above 45 & 36 & 24 \\
\hline Total & 150 & 100 \\
\hline
\end{tabular}

The above table shows that zero percentage of the respondents are below 15years, $31.3 \%$ are $16-25,44.7 \%$ of age group $26-45$ and $24 \%$ of the respondents are above the age of 45 .

Table 2: Showing Occupation of the Respondents

\begin{tabular}{|c|c|c|}
\hline Occupation & No. of respondents & Percentage \\
\hline Students & 79 & 52.7 \\
\hline Business & 37 & 24.7 \\
\hline Employee & 24 & 16 \\
\hline Others & 10 & 6.7 \\
\hline Total & 150 & 100 \\
\hline
\end{tabular}

The sample constitutes $52.7 \%$ of students, $24.7 \%$ business men, $16 \%$ employees and $6.7 \%$ others.

Table 3: Showing Gender of the Respondents

\begin{tabular}{|c|c|c|}
\hline Gender & No. of respondents & $\%$ \\
\hline Male & 86 & 57.3 \\
\hline Female & 64 & 42.7 \\
\hline Total & 150 & 100 \\
\hline
\end{tabular}

In the sample $57.3 \%$ of respondents are male and $42.7 \%$ are female.

Table4: Showing Awareness of Home Shopping Websites

\begin{tabular}{|c|c|c|}
\hline Awareness & No. of the respondents & Percentage \\
\hline Yes & 136 & 90.7 \\
\hline No & 14 & 9.3 \\
\hline Total & 150 & 100 \\
\hline
\end{tabular}

From the table it can be observed that $90.7 \%$ of respondents are aware of home shopping websites while $9.3 \%$ are unaware about the home shopping.

Table5: Source of Awareness about the Home Shopping Websites

\begin{tabular}{|c|c|c|}
\hline Personal & No. of respondents & Percentage \\
\hline Friends/Relatives & 52 & 38.2 \\
\hline Televisions & 22 & 16.2 \\
\hline Internet & 57 & 41.9 \\
\hline Others specify & 4 & 2.9 \\
\hline Total & 136 & 100 \\
\hline
\end{tabular}

The above table shows that $38.2 \%$ of respondents to know the home shopping through friends and relatives, $16.2 \%$ through television, $41.9 \%$ through Internet and $2.9 \%$ through other devices. 


\section{International Journal of Science and Research (IJSR) \\ ISSN (Online): 2319-7064 \\ Index Copernicus Value (2013): 6.14 | Impact Factor (2014): 5.611}

Table 6: Showing Reason For Joining Home Shopping Networking Websites

\begin{tabular}{|l|c|c|}
\hline \multicolumn{1}{|c|}{ Reason for joining } & $\begin{array}{c}\text { No. of the } \\
\text { respondents }\end{array}$ & $\%$ \\
\hline $\begin{array}{l}\text { To compare prices of product of same } \\
\text { category }\end{array}$ & 59 & 43.4 \\
\hline $\begin{array}{l}\text { To compare differentiated product of same } \\
\text { category }\end{array}$ & 36 & 26.5 \\
\hline To Purchase & 21 & 15.4 \\
\hline For sharing information & 18 & 13.2 \\
\hline Just for time pass & 2 & 1.5 \\
\hline \multicolumn{1}{|c|}{ Total } & 136 & 100 \\
\hline
\end{tabular}

The above table shows that $43.4 \%$ of the respondents enter in the websites for the purpose of comparing prices of the product, $26.5 \%$ just to compare differentiated product of same category, $15.4 \%$ to purchase the product, $13.2 \%$ to acquire the knowledge of the product and remaining $1.5 \%$ for time pass.

Table7: Showing Purpose of Browsing Internet Per Day

\begin{tabular}{|c|c|c|}
\hline Personal & No. of respondents & $\%$ \\
\hline Shopping websites & 34 & 25 \\
\hline Social networking website & 52 & 38.2 \\
\hline Study related website & 28 & 20.6 \\
\hline Others specify & 22 & 16.2 \\
\hline Total & 136 & 100 \\
\hline
\end{tabular}

The above table shows that $25 \%$ of the respondents browse the internet shopping websites, $38.2 \%$ for social networking, $20.6 \%$ study related materials and $16.2 \%$ for other websites.

Table 8: Showing Respondents Profiles In Online Shopping Websites and Other Websites

\begin{tabular}{|l|c|c|}
\hline \multicolumn{1}{|c|}{ Profile } & $\begin{array}{c}\text { No. of the } \\
\text { Respondents }\end{array}$ & $\%$ \\
\hline 1. jabong.com & 34 & 9.4 \\
\hline 2. yepme.com & 28 & 7.8 \\
\hline 3. junglee.com & 32 & 8.9 \\
\hline 4. homeshop18.com & 56 & 15.5 \\
\hline 5. yebhi.com & 13 & 3.6 \\
\hline 6. snapdeal.com & 34 & 9.4 \\
\hline 7. ebay.in & 26 & 7.2 \\
\hline 8. Flipkart.com & 48 & 13.3 \\
\hline 9. shopping.rediff.com? & 13 & 3.6 \\
\hline 10. indiafreestuff.in & 12 & 3.3 \\
\hline 11. shopping.indiatimes.com & 28 & 7.8 \\
\hline 12. indiaplaza.com & 2 & 0.6 \\
\hline 13. futurebazaar.com & 7 & 1.9 \\
\hline 14. shoppingmantra.com & 0 & 0 \\
\hline 15. fashionandyou.com & 9 & 2.5 \\
\hline 16. hamaramall.com & 13 & 3.6 \\
\hline 17. fashionara.com & 6 & 1.7 \\
\hline Total & 351 & 100 \\
\hline
\end{tabular}

The above table shows that the homeshop18.com get a maximum response of $15.5 \%$. Home shop 18 is also maintains a TV channel and hence, it has a higher popularity in this region. It is also found that Flipkart.com is in the second position at $13.3 \%$ whereas snapdeal.com and jabong.com are in $3^{\text {rd }}$ position with $9.4 \%$.
Table9: Showing Time Period of Respondents who are Using Internet

\begin{tabular}{|c|c|c|}
\hline Time period & No. of respondents & Percentage \\
\hline 0-2 hours & 83 & 55.3 \\
\hline 2-4 hours & 35 & 23.3 \\
\hline 4-6 hours & 15 & 10 \\
\hline Above 6 hours & 17 & 11.3 \\
\hline Total & 150 & 100 \\
\hline
\end{tabular}

The above table shows that $55.3 \%$ of the respondents browses the internet $0-2$ hour, $23.3 \%$ browses $2-4$ hours, $10 \%$ browses $4-6$ hours and remaining $11 \%$ browses 6 hours and above per day. It is also found that the student community is the highest user of internet.

Table 10: Showing Time Being Spent By The Respondents To Their Favourite Shopping Websites

\begin{tabular}{|c|c|c|}
\hline Time spending (minutes) & No. of respondents & Percentage \\
\hline Less than $15 \mathrm{~min}$ & 45 & 33.1 \\
\hline $15-30$ & 51 & 37.5 \\
\hline $30-45$ & 16 & 11.8 \\
\hline Above 45 & 24 & 17.7 \\
\hline Total & 136 & 100 \\
\hline \multicolumn{2}{|l}{}
\end{tabular}

The above table shows that $33.1 \%$ of the respondents spend less than 15 minutes on their favorite shopping sites, $37.5 \%$ spend 15 to 30 minutes, $11 \%$ spend 30 to 45 minutes and remaining $17.7 \%$ of the respondents spend their time more than 45 minutes.

Table11: Showing Trusting the Shopping Websites

\begin{tabular}{|c|c|c|}
\hline Trusting the information & No. of respondents & Percentage \\
\hline Yes & 62 & 45.6 \\
\hline No & 23 & 16.9 \\
\hline Sometimes & 51 & 37.5 \\
\hline Total & 136 & 100 \\
\hline
\end{tabular}

From the above table, it is observed that $45.6 \%$ of the respondents trusting the shopping sites from the point of payment and delivery of the product, $16.9 \%$ of the respondents are not trusting, $37.5 \%$ of the respondents trusting the information only sometimes.

Table12: Showing the Consideration of Ads that Can Be Seen On Respondent's Profile Or Any Webpage Relevant To Their Interest

\begin{tabular}{|c|c|c|}
\hline Response & No. of respondents & Percentage \\
\hline Yes & 46 & 33.8 \\
\hline No & 22 & 16.2 \\
\hline Occasionally & 68 & 50 \\
\hline Total & 136 & 100 \\
\hline
\end{tabular}

From the above table , $33.8 \%$ are consider that ads seen by them are relevant to their interest, $16.2 \%$ are consider that ads seen by them are not relevant to their interest, $50 \%$ are consider occasionally ads seen by them are relevant to their interest. 


\section{International Journal of Science and Research (IJSR) \\ ISSN (Online): 2319-7064}

Index Copernicus Value (2013): 6.14 | Impact Factor (2014): 5.611

Table 13: Showing Whether Home Shopping Websites Are Really Useful for the Effective Shopping Or Not

\begin{tabular}{|c|c|c|}
\hline Response (Really useful) & No. of respondents & Percentage \\
\hline Yes & 48 & 35.3 \\
\hline No & 27 & 19.9 \\
\hline Sometimes & 38 & 27.9 \\
\hline May be (Don't know) & 23 & 16.9 \\
\hline Total & 100 & 100 \\
\hline
\end{tabular}

From the above, $35.3 \%$ of the respondents are believing that the home shopping websites are useful for effective shopping, $19.9 \%$ believes that the home shopping websites are not useful for effective shopping, $27.9 \%$ believes that the home shopping websites are sometimes useful, $16.9 \%$ are believing that the home shopping websites may be useful for effective shopping.

\section{Findings and Conclusions}

a) The highest percentage $(67 \%)$ of respondents are from the age group of 31 to 45 .

b) It was found that students show lots of interests $(52.7 \%)$ in using internet.

c) In the sample there are $57.3 \%$ of male respondents and $42.7 \%$ of female respondents.

d) It can be observed that $90.7 \%$ of respondents are aware of home shopping websites.

e) It was found that $43.4 \%$ of the respondents joining the home shopping websites for the purpose of comparing prices of product.

f) It was found that the highest \% i.e. 95 of the respondents browse the internet per day for social networking and $78 \%$ for home shopping.

g) The highest percentage of the respondents has their profile in ,homeshop18.com ${ }^{\text {ee }}$ and second highest percentage of people has ,flipkart.com“e

h) It was found that the highest percentage $(55.3 \%)$ of the respondents browse the internet per day is 0 to 2 hours and $23.3 \%$ of the respondents browse the internet between 2 to 4 hours.

i) The survey shows that the highest percentage $(37.5 \%)$ of the respondents are using the home shopping sites from 15 to 30 .

j) It was found that $45.6 \%$ of the respondents trust home shopping sites.

k) The highest percentage $(33.8 \%)$ of the respondents considers the advertisement in any websites.

1) It was found that $35.3 \%$ of the respondents feel that the home shopping is useful for effective shopping.

\section{Conclusion}

The increase trends of the use of internet reduce the difference between the consumer and seller now a day. Similarly, shopping with a large variety of commodities from the comfort zone of the customer by comparing prices increases the general tendency of Home shopping in the country. Hence, it creates a new business opportunity for the seller and of course creates more comprehensive opportunity of the customer. The figures say that there is an increasing trend of growth of home shopping in the country. The only necessity is to check the safety measures by the customer while shopping in different web sites.

\section{References}

[1] J. Jaya Pradha, "A Study on Consumers"e Preferences Towards Social Networking Websites", International Journal of Multidisciplinary Research Vol.2 Issue 6, June 2012, ISSN 22315780

[2] Mr. Madhur Raj Jain, Ms. Palak Gupta and Ms. Nitika Anand, "Impact of Social Networking Sites in the Changing Mindset of Youth on Social Issues-A Study of Delhi-NCR Youth"

[3] Michael Sonntag, Susanne Reisinger, "Important Factors for E-Commerce"

[4] Alev M. Efendioglu, " E-commerce in Developing Countries: Issues and Influences"

[5] Walt Scacchi, "A Case Study in Electronic Commerce and Open Source Software Development"

[6] Yannis Bakos, "The Emerging Landscap of Retail Ecommerce"

[7] R. Rajaraman, "Electronic Commerce"

[8] Alireza Gharegozi, Ebrahim Faraji and Lachin Heydari, "The Study of Information Technology Effect on Ecommerce Growth"

[9] Www.google.com

[10] Www.wikipedia.com 